\title{
İnci Enginün, Ahmet Hamdi Tanpınar, İstanbul, Dergâh Yayınları, 2019, 292 s., ISBN: 978-975-995-999-9
}

\author{
Uğur Mantu ${ }^{1}$
}

${ }^{1}$ Uzman, Atatürk Kültür, Dil ve Tarih Yüksek Kurumu, Ankara, Türkiye

ORCID: U.M. 0000-0002-3505-2033

Sorumlu yazar/Corresponding author:

Uğur Mantu, Atatürk Kültür, Dil ve Tarih Yüksek Kurumu, Ankara, Türkiye

E-mail: ugur.mantu@gmail.com

İnci Enginün'ün çeşitli mecralarda neşredilmiş yazı ve konuşmalarının belirli tema ve kişiler odağında, müstakil ciltler hâlinde okura sunulması düşüncesinin bir ürünü olan Ahmet Hamdi Tanpınar, Dergâh Yayınları tarafından Ekim 2019'da yayımlandı. Enginün'ün Ahmet Hamdi Tanpınar ve eserleri hakkında muhtelif dergi ve armağan kitaplarda yer alan yazıları, yine bu minvalde kendisiyle yapılmış söyleşiler ve çeşitli isimlerce hazırlanmış Tanpınar eserleri için kaleme aldığı önsöz ve tanıtma yazıları eserin içeriğini oluşturmaktadır.

Kitabının önsözünde yaklaşık altmış yıllık bir süreci ihtiva eden Ahmet Hamdi Tanpınar okumalarının gerek kendisi gerekse diğer okur ve araştırmacılar üzerindeki yoğun ve ufuk açıcı etkisini vurgulayan İnci Enginün, Tanpınar'ın “dikkat”lerini takip etmenin onun eserlerinde yer verdiği kişi ve meseleleri daha derinden kavramaya yaptığı katkının altını çizmektedir.

İnci Enginün'ün Tanpınar'ı ve eserlerini çeşitli biyografik veriler, yazarın günlük ve mektupları ile başta Mehmet Kaplan'ınkiler olmak üzere ona dair kaleme alınmış inceleme, 
eleştiri ve hatıra yazılarından da yararlanarak farklı açılardan değerlendirdiği Ahmet Hamdi Tanpınar'ı içerik bakımından, Enginün'ün de önsözde belirttiği gibi, üç bölüme ayırmak mümkündür. Kitabın en geniş kısmını oluşturan birinci bölümde Tanpınar'a dair incelemeler ve günlük hayatta yaşanan olay ve durumlara yönelik Tanpınarvâri bakışın uyandırdığı çağrışımlardan doğan yazılar yer almaktadır. Bu bölümdeki yazılara kısaca değinmek, eseri merak eden okuyucular açısından da faydalı olacaktır. Enginün, "Son Durak: Zaman Kırıntıları" başlıklı yazısında Tanpınar poetikasının önemli kavramları arasında bulunan “ayrılık”, "bölünmüşlük”, "bütünleşme özlemi” ve "korku” üzerinde durmakta ve yazarın çeşitli eserlerinden hareketle Tanpınar'ın eşikte kalmışlığının doğurduğu psikolojik etkilerin izlerini sürmektedir.

Ahmet Hamdi Tanpınar'ın fikirle estetiği buluşturduğu romanı Huzur için alışılmışın dışında bir okuma önerisi getiren "Hangi Huzur"da söz konusu eserin bir de "eşik" ve "ayna" kavramları merkeze alınarak değerlendirilmesi tavsiye edilmektedir. Enginün bunun yanında romana isim olarak seçilen "huzur" kelimesinin "bir yerde, bir şeyin karşısında bulunmak" anlamı hatırda tutularak romana yaklaşmanın okuyuculara metni yorumlamada farklı kapıları aralamanın yolunu açabileceğine dikkat çekmektedir. "Hangi Huzur”la birlikte okunabilecek “Suat: Tanpınar'ın Musallat Kahramanı” başlıklı yazı, Ahmet Hamdi Tanpınar'ın hayat karşısındaki durumu ve düşünceleri bakımından aykırı kahramanlarından biri olarak kabul edilen Suat'tan yola çıkılarak Tanpınar romancılığının bazı kilit noktalarını yakalama çabasını içermektedir. Enginün, söz konusu yazısında Huzur'u ve Suat'in Mektubu'nu bir arada ele alıp yazarın diğer eserlerinden de yararlanarak onun kahramanları üzerinden kendi kişilik özelliklerini nasıl yansıttı̆̆ını örneklerle ortaya koymaktadır.

Tanpınar'ın belirli bir zaman dilimi içerisindeki toplumsal değişimi farklı boyutlarıyla ele aldığı nehir romanının bir parçası olan Sahnenin Dışındakiler'in değerlendirildiği “Sahnenin Dışındakiler”, özellikle Enginün'ün Tanpınar'da insanın ele alınış şekline yönelik şu tespitiyle dikkat çekmektedir: "İnsanın, etrafindaki terkibin bir parçası olduğuna inanan yazar, onlarl geniş çevreleriyle, bir ufactk hadisede derinleştirilen psikolojileriyle verir. Bunu yaparken de imajlarla zengin, Türkçenin en yüksek mizahî ve ironik üslubuyla, onları ve hayat karşısındaki tavırlarını anlatır." (s. 37)

Ahmet Hamdi Tanpınar'ın sağlığında tamamlayamadığı eserlerinden biri olan ve onun vefatından sonra Güler Güven' in yoğun gayreti neticesinde okuyucuya ulaşan romanı Aydaki Kadın, Tanpınar'ın diğerleri kadar üzerinde durulmayan eserlerinden biri olarak kabul edilebilir. İnci Enginün, “Aydaki Kadın'ın Kaynakları Üzerine” adlı yazısıyla, özellikle günlüklerden hareketle, hem söz konusu romanın yazılma ve okurla buluşma serüveni üzerinde durmakta hem de Tanpınar üzerinde tesiri bulunan yazar ve eserlerden hareketle metnin göndermelerinin anlaşılmasına katkıda bulunmaktadır. Ayrıca bu romanda yer alan Selim ile Huzur'un Mümtaz'ını benzerlik ve farklılıkları yönünden mukayese eden Enginün, Mümtaz'da olduğu gibi Selim'de de yazar-karakter özdeşleşmesinin örneklerinin bulunduğunu ortaya koymaktadır. 
İnci Enginün'ün Tanpınar'ın mekân algısına dair önemli değerlendirmelerini içeren iki konuşmasının yazılı hâlini teşkil eden "Beş Şehir" ve "Şehirler Karşısında Tanpınar", yazarın hayatının dönüm noktalarında ikamet ettiği Ankara, Antalya, Bursa, Erzurum, Paris ve özellikle de İstanbul'a yönelik yaşantı ve kültürel birikimle bütünleşen estetik bakışının eserlerine yansımalarından örnekler vererek Tanpınar okuruna rehberlik etmektedir.

Enginün, Tanpınar'ın topluma ve kendisinin toplum içindeki konumuna dair his ve fikirlerinden çizgileri kahramanlarının ruhi ve fiziki yapılarına yansıttığı hikâyelerinden biri olan "Teslim"deki yazar-kahraman bütünleşmesi üzerinde durduğu, eserle aynı başlığ taşıyan yazısında "kader" ve "trajedi”" kavramlarını öne çıkararak metni tahlil etmektedir.

Tanpınar'ın şairliği üzerinde durulan “Tanpınar'ın Şiir Çalışması” ve “Tanpınar'ın Mükemmellik Çabası: Şiir Müsveddeleri Üzerinde Bir Deneme" başlıklı yazılarda onun yarım kalan yahut zaman içerisinde çeşitli değişikliklere uğrayan şiirlerinden hareketle sınırları zorlayan bir titizlik etrafında şekillenen şiir anlayışı ve eserleri arasındaki parçabütün ilişkisine dikkat çekilmektedir.

Hayatının önemli bir kısmını savaşın ve onun beraberinde getirdiği yıkıcı ve dönüştürücü sonuçların tesiri altında geçiren Ahmet Hamdi Tanpınar'ın savaşa dair şahsi tecrübeleri ile gerek okumaları gerekse çevresinden edindiği tarihî ve kültürel birikimini eserlerine aksettirmesi tabiidir. İnci Enginün, “Tanpınar'ın Romanlarında Savaş” başlığını taşıyan yazısında Tanpınar'ın romanlarını savaş temi merkezinde incelikli bir değerlendirmeye tabi tutarak savaş psikolojisinin bireysel ve toplumsal alandaki yansımalarını örneklerle göstermektedir. Savaşı ve sonrasını salt bir zafer ya da yenilgiden ibaret bir tarih sayfası olarak yansıtmaktan ziyade onun arka planında gelişen kültürel, siyasi ve sosyolojik değişimlere odaklanan Tanpınar, roman kahramanlarını da bu minvalde düşündürüp konuşturarak toplumsal çalkantıların sebeplerini açığa çıkarma gayretindedir.

Ahmet Hamdi Tanpınar'a dair okuma ve araştırmalarının kaçınılmaz neticelerinden biri olarak olaylara ve durumlara zaman zaman Tanpınar merceğinden bakmaktan kendini alamayan İnci Enginün'ün 17 Ağustos depreminin ardından yazdığı "Sanatçı ve Deprem", Tanpınar'ın gerçek bir olaydan esinlenerek kaleme aldığını belirttiği “Erzurumlu Tahsin” adlı öyküsünden hareketle depremin toplum ve fert hayatında yol açtığı sarsıntıları işlemektedir.

İnci Enginün, kişiliğindeki bölünmüşlüğün yaşamına ve eserine yoğun bir şekilde aksettiği Tanpınar'ın kendiyle cedelleşmesini ve bunun edebî görünümlerine dair değerlendirmelerini “Tanpınar'ı Düşünürken” başlıklı yazısında ortaya koymuştur.

Eserlerinde Türk tarihi ve kültürünün can alıcı meselelerini zengin bir çağrışım dünyasının getirdiği çarpıcı sembollerle işlemeyi düstur edinen Ahmet Hamdi Tanpınar'ın kavramlara ve sembollere yüklediği anlamları idrak edebilmek, okurunun onunla daha derin ve kuvvetli bir bağ kurmasına vesile olacaktır. "Tanpınar ve Semboller" başlıklı yazısında yazarın soyadı da dâhil olmak üzere onun eserlerinde kullandığı çeşitli sembollerin izlerini süren 
İnci Enginün, böylece okuyucunun Tanpınar'ın metinlerine daha farklı bir gözle bakmasına imkân tanımaktadır. Özellikle "su”, “aydınlık", "yılan” ve "şehir" sembolleri üzerinden Tanpınar'ın şiirlerini ve nesirlerini inceleyen Enginün, böylece yazarla okuru arasındaki mesafenin daralmasına yardımcı olmuştur.

Ahmet Hamdi Tanpınar'ın eserlerinde okuyucu ve araştırmacılara yeni kapılar aralayacak unsurlardan biri de mimaridir. Şehri ve mimari eserleri metinlerinde basit bir arka fon olmanın oldukça ötesinde bir işlevde kullanan Tanpınar'ın mekâna ve eşyaya bakışındaki incelikler ve bu kavramlar üzerinden modernleşme sürecimize dair tespitler "Mimarî Karşısında Tanpınar"da seçilmiş örneklerin ışığında ele alınmaktadır.

Şiirleri haricindeki eserlerinde toplumumuzun son birkaç yüzyıldır yaşadığı medeniyet krizini ve kültürel bocalamayı farklı boyutlarıyla işleyen Tanpınar'ın roman ve öyküleri genellikle bu büyük mesele ekseninde incelendiğinden, İnci Enginün'ün de belirttiği gibi, bazı unsurlar arka planda bırakılarak ya hiç üzerinde durulmamış ya da bu unsurlara kısa ve sathi temaslarla yetinilmiştir. Kültürün ve geleneğin kesintiye uğramadan sürdürülmesinde büyük öneme sahip olan "çocuk"un Tanpınar eserlerindeki konumu belki de müstakil bir çalışmayı gerektirecek derecede mühimdir. Yazarın, roman ve hikâyelerinde "çocuk”a dair değerli tespitleri ihtiva eden "Tanpınar ve Çocuklar" başlıklı yazı bu açıdan yeni çalışmalara kapı açma mahiyetini taşımaktadır.

Babasının görevi sebebiyle Osmanlı coğrafyasının çeşitli şehirlerini dolaşan ve buralarda geçirdiği yılların hafızasında bıraktığı izlere eserlerinde birer otobiyografik unsur olarak yer veren Tanpınar'ın metinlerine kaynaklık eden mekânlardan biri de Kerkük'tür. Enginün'ün “"Bir Zamanlar'dan Kalan” adlı yazısında üzerinde durduğu gibi Tanpınar'ın hayatında Kerkük ve bu şehirde geçirdiği yıllarda ikamet ettiği evlerin hikâye ve romanlarında yer verdiği olay ve kahramanların işlenmesinde büyük tesiri olacaktır.

Günümüzde tüketil(e)meyen bir hazine olarak değerlendirilen Tanpınar külliyatı yazar hakkında yapılan incelemeler ve bulunan yeni belgelerle zenginleşmektedir. Tanpınar'a yönelen ilginin sebeplerini “Günümüze Yansımalarıyla Tanpınar” başlıklı yazısında araştıran İnci Enginün, bu durumun ortaya çıkışında öncelikle merhum Mehmet Kaplan'ın hem derslerinde hem de yazılarında Tanpınar'ın tanınmasına yaptığı katkının altını çizmektedir. Bunun haricinde İkinci Yeni gibi anlaşılmak için çaba gerektiren metinlerin kabul görmesi ve Tanpınar'ın eserlerinin yabancı dillere tercüme edilmesi gibi sebeplerden bahseden Enginün, bununla birlikte Tanpınar üzerinde çalışma yapanlardan bazılarının onunla aynı müktesebata sahip olmamasının ortaya konan metinlerin değerini düşürdüğüne dikkat çekmektedir.

İnci Enginün'ün Ahmet Hamdi Tanpınar adlı kitabı okuyucusu için güzel bir sürprizi de barındırmaktadır. Enginün'ün daha önce herhangi bir mecrada yayımlamadığ ve Mehmet Kaplan" adlı yazısı ilk defa bu kitap vesilesiyle okuyucuyla buluşmaktadır. Yazısında Ahmet Hamdi Tanpınar ve Mehmet Kaplan'ı bilim adamı ve eleştirmen kimlikleri özelinde ele alan Enginün hem bu iki ismin eserlerini eleştirel bir gözle değerlendirmekte 
hem de birbirlerine olan katkıları üzerinde durmaktadır. "Tanpınar ve Mehmet Kaplan"ın bir başka önemli yanı da Enginün'ün XIX. Asır Türk Edebiyatı Tarihi hakkında verdiği bilgidir. Enginün, Tanpınar'ın Behice ve Mehmet Kaplan'a hediye ettiği nüshadan hareketle kitabın ilk neşir tarihinin 1942 olduğunu ifade etmektedir.

Kitabın ilk bölümünün son yazısı olan “Tanpınar da Görseydi”, İnci Enginün'ün "Van Gogh Alive" adlı sergiye yönelik izlenimlerini içermektedir. Enginün, sergiyi gezerken Van Gogh'un eserlerine bir de onu çok seven Tanpınar'ın gözüyle bakarak kendisine onun rehberlik ettiğini dile getirmiştir.

Ahmet Hamdi Tanpınar'ın ikinci bölümü olarak nitelendirebileceğimiz "Söyleşiler”de İnci Enginün'ün, bir kısmında Zeynep Kerman'la birlikte, Tanpınar ve eserleri hakkında çeşitli isimler tarafından sorulan sorulara verdiği cevaplar yer almaktadır. Soruların genellikle İnci Enginün ve Zeynep Kerman tarafından hazırlanan Günlüklerin Işı̆̆̆ında Tanpınar 'la Baş Başa adlı esere ve Tanpınar'ın hayatı boyunca muzdarip olduğu "sükût suikastı"na ve son dönemlerde kendisine artan ilginin sebeplerine yönelik oluşu dikkat çekicidir.

Eserin son bölümü ise İnci Enginün'ün Ahmet Hamdi Tanpınar'ın Dergâh Yayınları'nca neşredilen kitaplar için yazmış olduğu açıklayıcı önsözlerden ve Tanpınar'dan Notlar, Tanpınar'in Mektupları, Saatleri Ayarlama Enstitüsü ve Ahmet Hamdi Tanpınar'dan: Düşünceler, Görüşler, Özdeyişler adlı kitaplara yönelik tanıtma yazılarından oluşmuştur.

Tanpınar için “Tanpınar hiçbir sözünü bağıra çağıra, abartılarla anlatmaz. Onun kısık sesle anlattıkları ise, hiç ummadı̆̆ımız anda bir çare sığınă̆ına dönüşür. Okuyucusunun içinde devam eden sesi, cümle cümle en muhtaç olduğumuz anda, aydınlatıcı bir ufku gözler önüne serer. Sanıyorum Tanpınar'ın git gide artan etkisi, insanı büyüsüne alan güçlü anlatımının okuyucuda yaşamasında kaynaklanmaktadır." (s. 134) tespitini yapan İnci Enginün'ün Ahmet Hamdi Tanpınar adlı kitabı, hem Türk edebiyatının her okuyuşta yeni bir ufuk açan zengin kalemi Ahmet Hamdi Tanpınar'1 kişiliği ve eserlerinin çeşitli veçheleriyle tanımak hem de bir Tanpınar okurunun yarım asrı aşan okuma macerasıyla ortaya çıkan tespitleri görmek açısından kıymetli bir eser olarak okurunu beklemektedir. 
